\title{
Forventninger og ambitioner i skriftlige projekter: erfaringer omkring to metaforer og en figur
}

\section{Anker Helms Jørgensen, lektor i forskningsgruppen Innovative Communication}

på IT-Universitetet $i$ København.

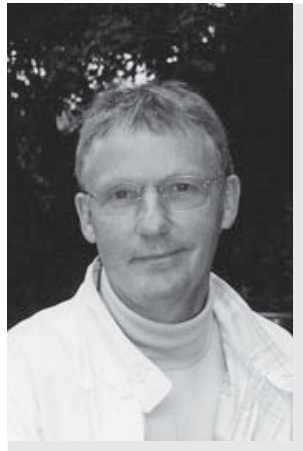

Anker Helms Jørgensen er lektor i forskningsgruppen Innovative Communication på IT-Universitetet i København. Hans forskningsområde er Human-Computer Interaction, hvor han gennem årene har arbejdet med en række områder: fra epistemologi over designpraksis til mental arbejdsbelastning. Hans nuværende forskningsfelt er brugergrænsefladernes historie.

Han er uddannet datalog fra Københavns Universitet og har arbejdet som systemudvikler og selvstændig konsulent. Inden ansættelsen på IT-Universitetet i København var han i en årrække lektor i informationspsykologi ved Københavns Universitet.

\section{Reviewet artikel}

Undersogelser viser, at der ofte er betydelige forskelle mellem de studerendes og vejledernes forventninger til niveauet $i$ universitetsspecialer. Denne artikel prosenterer og diskuterer en rakke erfaringer med handtering af forventninger og ambitionsniveau $i$ vejledning $i$ skriftlige universitetsopgaver, baseret på to metaforer og en enkel grafisk figur, som har vist sig meget nyttige. Artiklen argumenterer ydermere for, at feedback på studerendes rapportudkast toet på aflevering kan vore med til at bygge en bro mellem vejledning og bedommelse. Artiklens hensigt er-gennem identifikation af forskellene $i$ forventninger og deres arsager - at italescette disse og derved bidrage til at reducere forskellene.
Skriftlige universitetsprojekter er en væsentlig studieaktivitet, der gør det muligt for de studerende at sætte deres fingeraftryk indenfor et afgrænset område og opnå en dyb indsigt - ikke mindst i specialer. Sådanne projekter foregår oftest under tæet vejledning, og der opstår som regel en tillidsfuld relation mellem de studerende og vejlederen. Imidlertid afsluttes alle skriftlige universitetsprojekter med en bedømmelse - en karakter. Her træder forskelle mellem de studerendes og vejlederens forventninger til niveauet tydeligt frem: De studerende făr ofte en lavere karakter end forventet. Dette kan være en kilde til vrede, skuffelse og frustration - ja ligefrem oplevelse af krænkelse og svigt, som beskrevet i Rienecker, Harboe og Jørgensens bog Vejledning - en brugsbog for opgave- og specialevejledere på videregående uddannelser $(2005,289)$.

At der er forskel i forventninger dokumenteres af Thomas Harboes undersøgelse »De studerendes forventninger til specialevejledning - en spørgeskemaundersøgelse« fra Københavns Universitet (2000). Gennemsnittet af de specialestuderendes forventede karakter var på humaniora 10.35 og på samfundsfag 9.96. Dette suppleres afThomas Harboe og Rikke von Müllens nye undersøgelse fra 2006 »De studerendes forventninger til specialevejledningen - en spørgeskemaundersøgelse på Samfundsvidenskab og Jura«, hvor gennemsnitsforventningen var 10.2. Til sammenligning var gennemsnittet 9.5 ifølge Rienecker mfl. $(2005,54)$, mens det er 9.6 på DPU iflg Thomas Harboes rapport "Akademisk opgavevejledning - en handlingsorienteret analyse af 51 udvalgte klagesager« $(2005,54)$, og 9.8 på IT-Universitetet i København. Til sammenligning 
var gennemsnittet 9.3 i de specialer jeg har vejledt på IT-Universitetet.

Blandt de tre væsentligste tiltag nævnt i litteraturen til at imødegå forskelle mellem de studerendes og vejleders forventninger er tidlig forventningsafstemning til både proces og niveau, eksplicitering af bedømmelseskriterier og konsekvent basering af vejledningen på skriftligt materiale (Harboe og von Müllen, 2006, 9; Rienecker mfl. 2005, 60, 293) og rapporten »Skriftlige opgaver og vejledning« fra Danmarks Evalueringsinstitut (2000).

Denne artikel følger denne tråd, idet den præsenterer og diskuterer erfaringer med håndtering af forventninger og ambitioner til niveau i skriftlige universitetsprojekter. Artiklens mål er - gennem identifikation af forskellene i forventninger og deres årsager - at italesætte disse og derved bidrage til at reducere forskellene.

Artiklen er disponeret således: Først beskrives den teoretiske baggrund, hvorefter min vejledningspraksis præsenteres i nogen detalje, eftersom erfaringerne er meget kontekstbestemte. Dernæst opridses min metaforisk baserede begrebsliggørelse af projekters størrelse og kompleksitet som hovedelementer i ambitioner: at bygge en garage, et hus eller et palads og at gå på en vej. Illustreret omkring en enkel figur skitseres vejledningserfaringerne $\mathrm{i}$ tre faser i det samlede vejledningsforløb fra start til bedømmelse. Herpå følger en diskussion af feedback på rapportudkast tæt på aflevering, herunder "blåstemplingsfælden", og der rundes af med en konklusion.

\section{Teoretisk baggrund}

Eftersom artiklen fokuserer på forventninger og ambitioner er det nærliggende at starte med at skyde sig ind på hvad dette egentlig er. En udmærket definition er "Ambition: an earnest desire for some type of achievement or distinction, as power, honor, fame, or wealth, and the willingness to strive for its attainment." (Dictionary.reference.com, 2006). Den indfanger både målet, dets betydning og den indsats der skal til for at nå målet. En tilsvarende præcis definition af forventning er: "An expectation, which is a belief that is centred on the future, may or may not be realistic. A less advantageous result gives rise to the emotion of disappointment. If something happens that is not at all expected it is a surprise. An expectation about the behavior or performance of another person, expressed to that person, may have the nature of a strong request, or an order.« (www.reference.com). Denne definition indfanger fint forventningens realisme og konsekvenser - ligesom en forventning kan påvirke andre til at tænke eller handle på bestemte måder.

Hvad angår pædagogisk teori har jeg taget et pragmatisk teoretisk udgangspunkt: Rienecker, Harboe og Jørgensens ovennævnte bog Vejledning - en brugsbog for opgave- og specialevejledere på videregående uddannel- ser (2005). Bogen er en guldgrube indenfor feltet: fra skrivepsykologi til institutionelle aspekter. Jeg trækker yderligere på bogen Forskningsveilederen af Handal og Lauvås (2006). Kapitel 9 »Veiledning og studenters ambisjoner« indeholder en lang række relevante pointer vedrørende forventninger og ambitionsniveau, blandt andet baseret på empiriske undersøgelser i Norge. Handal og Lauvås understreger således forventningers og ambitioners vigtighed "... forventninger er hoyst reelle fenomener som preger og styrer både tanker og handlinger hos oss, og som det derfor er all grunn til å ta alvorlig." (Handal og Lauvås, 2006, 150). Deres undersøgelser viser, at på trods heraf har kun halvdelen af vejlederne talt om dette - og bemærkelsesværdigt nok har kun en fjerdedel af studenterne oplevet det som et tema (Handal og Lauvås, 2006, 151).

I indfrielse af ambitioner er kriterier for akademisk kvalitet om noget en afgørende faktor. Men her står det meget skidt til: "Bare en tidel af veilederne $i$ vår undersøkelse sier at de snakker med studentene om kriterier for vurdering av oppgaven. Studentenes opplevelse stemmer godt med dette." (Handal og Lauvås, 2006, 159). Så der synes at være god grund til at tage fat $i$ disse emner, givetvis også i Danmark. Således beskriver Thomas Harboe i »Akademisk opgavevejledning - en handlingsorienteret analyse af 51 udvalgte klagesager", at studerende klager alene for at få en begrundelse for bedømmelsen $(2005,48)$.

\section{Min vejledningspraksis i skriftlige projekter}

Artiklens specifikke omdrejningspunkt er mange års erfaring som vejleder i skriftlige projekter på Københavns Universitet i fagene datalogi og psykologi og siden på ITU, hvor jeg siden 1999 har vejledt 60 projekter på kandidatstudiet, 17 specialer og 9 ph.d.-projekter.

På ITU vælger de studerende selv emne og så vidt muligt også vejleder. Projekterne administreres stramt med faste projektperioder og afleveringsfrister; således afsluttes $58 \%$ af specialerne indenfor det normerede halve år. Senest to uger inde i perioden skal de studerende aflevere en problemformulering og en metodebeskrivelse. I skriftlige projekter er der altid mundtlig eksamen, som afholdes senest en måned efter aflevering.

Mængden af vejledning i mine projekter synes efter dagens standard generøs: ugentlige møder i de korte projekter og i begyndelsen af de lange, ellers typisk møder hver 2. uge. Jeg bruger ganske meget tid på vejledning $\mathrm{i}$ de enkelte projekter, men i gennemsnit ikke mere end normen på IT-Universitetet: 1.6 STÅ produceret pr. 100 arbejdstimer, som svarer til ca. 30 timer pr. studerende $i$ et speciale.

Vejledningsmøderne varer typisk en time og er altid baseret på skriftlige materialer, der afleveres pr. email dagen for senest kl. 16.

I vejledningsmøderne starter jeg altid med at karak- 
terisere og vurdere dagens skriftlige materialer i forhold til projektets overordnede sigte, gerne knyttet an til det sidste vejledningsmøde. Derudover giver jeg mange og specifikke kommentarer - positive såvel som negative, præsenteret både mundtligt og skriftligt - om indhold, relevans, disponering, argumentation, teori, metode, analyser, synteser, sprog, form, osv. I vejledningen er jeg direkte, kritisk og konstruktiv.Jeg får ros for denne form af mange af mine studerende, selv om det er hårdt for dem at fă at vide, at det ikke er godt - eller godt nok.

Rienecker mfl. $(2005,89,166)$ skitserer fire kategorier af feedback, som jeg forsøger at dække: problemmarkerende, spørgende, instruerende, og kvalificerende og ydermere tre vejlederroller: ekspert og mesterlære, som jeg anvender i nogen grad, samt coaching, som jeg dyrker udpræget.

De vejledte projekter er primært i den empiriske genre og konstruktionsgenren, mens de rene teoretisk/analytiske projekter er ret sjældne. Blandt emnerne kan nævnes: mødet mellem æstetikken og user interfacet, synshandicappedes brug af internettet, udvikling af fleksibel grænseflade til PDA'er, og udvikling af metoder til forbedring af user experience i computerspil.

\section{To metaforer for ambitionsniveau}

Jeg opfatter ambitionsniveau som baseret på projektets størrelse og dets kompleksitet. Størrelsen vedrører omfanget af det planlagte produkt, for eksempel smalt/ bredt teori- og metodevalg, bredde/dybde i empiriske undersøgelser, omfanget af et koncept eller en implementering, grundigheden i en evaluering, projektets effekt for andre parter, og graden af dokumentation. Kompleksiteten vedrører processen: hvor svært projektet er begrebsmæssigt, metodisk, empirisk og konstruktionsmæssigt - hvor mange og hvilke kompetencer der skal i spil for at sejle skibet sikkert i havn.

Jeg anvender metaforer til at begribe og italesætte dette $^{1}$. For storrelsen anvender jeg en bygning som metafor: Man kan bygge en garage, man kan bygge et hus, eller man kan bygge et palads svarende til noget beskedent, noget gedigent, og noget imponerende. De tre niveauer svarer ikke direkte til de tre beståede karaktergrupper på 13-skalaen - men det kan være en nyttig tankefigur.

Vedr. kompleksiteten anvender jeg metaforen at gå $p a ̊$ en $v e j^{2}$. Det kan gøres på tre måder. For det første kan man holde sig på midten af vejen og gå hvor andre har gået før. Det er sikkert at gå der, der er ingen særlige forhindringer, man farer ikke vild, hvis ellers man holder øjnene åbne og tænker sig om. For det andet kan man prøve at nærme sig kanten af vejen. Man falder måske i grøften og kommer nok op igen - evt. ved vejleders hjælp - og opnår derved større indsigt både i fagområdet og sig selv. Og endelig kan man driste sig væk fra vejen, ud i vildnisset og finde noget nyt i det uudforskede land.

De to metaforer har vist sig nyttige til at skyde sig ind på de studerendes ambitioner, deres selvforståelse og deres forestillinger om processen og produktet. Metaforerne er enkle og har alligevel en betydelig dybde. Et afgørende aspekt ved de to metaforer er deres vekselvirkning: dels kræver det flere kompetencer at bygge et palads end en garage - specielt et godt palads - og dels har de studerende på den ene side mulighed for at lave en nyskabende garage eller et banebrydende hus, og på den anden side et palads med store huller, mangel på sammenhæng, dårlige overgange og elendig disponering (bemærk metaforernes analogi med elementer fra akademisk skrivning).

Metaforernes nytte illustreres af, at jeg jæevnligt har studerende, som uden blusel indledningsvis melder ud, at de går efter en tocifret karakter. Fint nok, men diskussionen kan let blive lidt forenklet og endda følelsesladet. For karakterskalaen er jo blot en-dimensional talrække, og mange af de studerende har en betydelig emotionelt ladet bagage med fra tidligere bedømmelser. De to metaforer er mere rummelige og indfanger både proces og produkt: Resultatet kædes sammen med processen i stedet for at fokusere snævert på en tal-angivelse for kvaliteten af et resultat, som ingen rigtig har nogen forestillinger om.

\section{En figur over vejleders forventninger til niveau}

I Figur 1 ses en enkel grafisk fremstilling af vejlederens forventninger til niveau i skriftlige universitetsprojekter i hele projektforløbet. Den vandrette dimension er tiden, der løber fra venstre mod højre, mens den lodrette dimension er niveau, her illustreret med 13-skalaen. Hen over projektet betragtes fire faser:

1. Startfase med etablering af projektet

2. produktionsfasen med det lange projektarbejde

3. færdiggørelsen af rapport op mod aflevering

4. bedømmelse.

Figuren skal forstås således: Forventningsfeltet er helt åbent i starten, da man som vejleder som oftest ikke kender de studerende. Forventningsfeltet indsnævres efterhånden som projektet skrider frem.Ved færdiggørelse foreligger der et endeligt rapportudkast. Projektet afsluttes med en bedømmelse og en karakter, indikeret med karaktersymbolerne K1, K2 og K3. Modellen skal naturligvis ikke tages bogstaveligt med hensyn til, hvor hurtigt eller langsomt tragten indsnævres, hvor meget den indsnævres og hvordan den hælder; her er den vist vandret, men både stigende og faldende forventninger forekommer jævnligt. 
Karakter

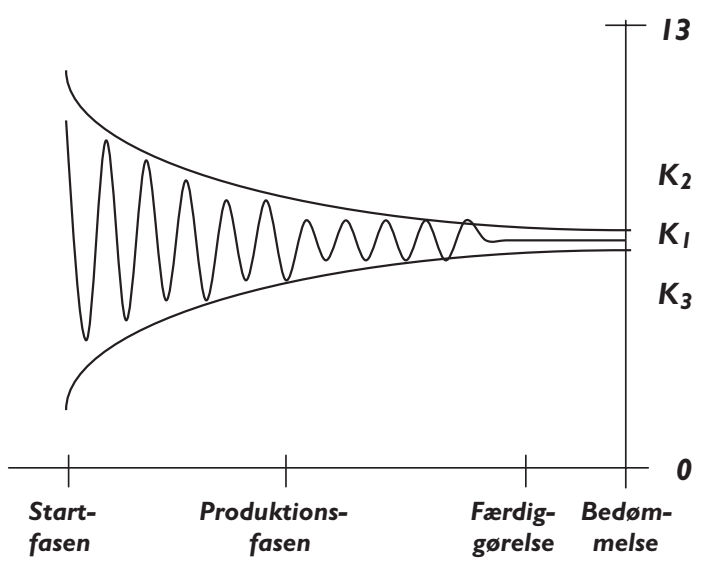

Figur 1: Grafisk fremstilling af vejlederens forventninger til niveau $i$ skriftlige universitetsprojekter

\section{Første fase: etablering af projektet}

Ved de første møder taler vi bredt om vores baggrunde, om det at lave projekt eller speciale, rammerne, ressourcerne, motivationen, ambitionerne, målene, osv. Drøftelserne om ambition tager udgangspunkt i metaforerne om at skabe en bygning og om at gå på vejen. Mere specifikt taler vi om emnet, tilgangen, problemformuleringen, teorirammen, metoderne, projektets genre (teoretisk/analytisk, empirisk eller konstruktion), arbejdsplan, disposition, titel, osv. I denne fase anvender jeg også ofte Blooms kognitive taksonomi, som ganske mange studerende kender (Bloom m.fl.: Taxonomy of educational objectives, 1956).

Centralt på dette tidspunkt er afklaring af mine forestillinger om match'et mellem de studerendes ambitioner, deres ressourcer og det planlagte produkt. Som vejleder er ens vigtigste opgave her at hjælpe de studerende med at afklare ambitionerne og matche dem til ressourcerne og produktet. Med andre ord: at få dem til at levere maksimalt, samtidig med at de føler, at de har ressourcer til at levere. I denne fase etableres hos mig det første billede af de studerendes ambitioner og hvad de faktisk magter, dels hvor meget potentiale de har, udover hvad de selv erkender, og endelig hvor meget man kan få frem af dette potentiale og hvordan.

\section{Anden fase: produktion}

Efter afklaringen i projektets første fase kører projektet mere eller mindre på skinner $i$ anden fase, "produktionsfasen«. Der er sjældent behov for dybere diskussioner af sigte og hensigt; retning og ramme er fastlagt. De studerende afleverer rutinemæssigt skriftlige produkter: dispositioner, referater af litteratur, kapiteludkast, planer for empiriske studier, analyser, prototyper, osv.

Jeg giver feedback på de studerendes materialer ud fra min forventning til niveau og ambition. Feedbacken består både af positive og negative elementer. Typiske eksempler på positiv feedback for et hus er "Fornuftig argumentation, relevant teori inddraget, fornuftige analyser, et godt grundlag for udvikling af koncept, velbegrundede designbeslutninger, rimeligt velskrevet."

Med disse konkrete eksempler på feedback er det oplagt at standse og spørge: Hvordan kan det tænkes, at de studerende opfatter en sådan feedback? Det kan meget vel være, at de opfatter det positive i feedbacken som det primære og niveau-skabende - for eksempel som pegende i retning af et palads, og at de kun opfatter det negative som nødvendige rettelser til det forestillede palads, som de så »bare« skal implementere - mens meningen var at karakterisere et hus med ligestillede plusser og minusser?

Undervejs betoner jeg sammenhængen mellem proces og produkt. Produktet vokser ud af processen, processen er ikke en del af produktet, men er basis for det. En tidlig skitse af produktet i form af en indholdsfortegnelse eller en disposition er nyttig, ligesom det undervejs er relevant at se på den fremvoksende helhed ved løbende at revidere dispositionen og indholdsfortegnelsen.

Med hensyn til ansvarsfordeling understreger jeg undervejs, at de studerende ikke skal gøre noget, fordi jeg siger det - de skal gøre det, fordi de synes, at argumenterne er gode. Dybest set handler vejledning om at udvikle de studerendes selvstændighed og deres evne til at træffe de rigtige beslutninger, baseret på god argumentation.

Mine forventninger ændres sjældent væsentligt i denne fase - om end det forekommer, både den ene vej og den anden vej. Et eksempel er Lasses speciale om mødet mellem æstetikken og user interfacet. Lasse var meget dygtig og meget ambitiøs. Jeg havde vejledt ham før, hvor han havde leveret fremragende opgaver. Det tegnede fint i starten, men efterhånden blev det for forsigtigt. Halvanden måned før aflevering fortalte jeg, at det fremtonende speciale ikke løftede sig og argumenterede for det. Lasse tog noget modstræbende kritikken til sig og gravede et par spadestik dybere. Resultatet blev et speciale til 11, som vi senere skrev en tidskriftsartikel om. I en procesevaluering efter specialets afslutning fortalte Lasse, at kritikken havde været meget hård at sluge, men erkendte også dens nødvendighed. Og det gik op for mig, at muligheden for et drop-out nok ikke havde været så langt væk, hvis ikke vi havde haft så god en personlig relation ${ }^{3}$.

Et andet eksempel er Steffen og Arne, der indledningsvis havde meldt ud, at de gik efter en tocifret karakter. De havde en original ide, og de var ambitiøse, men ikke særlig skrappe til at styre deres processer og bygge et helstøbt palads op. Så efter nogen tid fortalte jeg dem derfor flere gange, at det jeg hidtil havde set ikke pegede i retning af en tocifret karakter. Efterhån- 
den accepterede de denne mulighed og satsede på et hus. Men det endte faktisk med karakteren 10, fordi de til sidst fik styr på de noget løse dele.

\section{Tredje fase: $\bmod$ en afrundet helhed}

I denne fase nærmer projektet sig sin afslutning, kapiteludkastene er læst, bygningen begynder at træde klart frem, vekselvirkningen mellem del og helhed accentueres, den røde tråd ekspliciteres. Arbejdet er lavet, tankerne er tænkt - det eneste væsentlige indsatsområde er fremstillingen.

I denne fase har de studerende en unik mulighed for at lære noget om del-helhed og om laser-forfatter perspektiverne. Blandt andet derfor læser jeg konsekvent færdige rapportudkast 1-2-3 uger for aflevering, afhængig af projektets længde. Blandt de spørgsmål, der dukker op her, som ikke har kunnet adresseres substantielt tidligere i forløbet er:

- Giver titel, forside, abstract, indholdsfortegnelse, indledning og konklusion et dækkende billede af rapportens indhold?

- Er der et godt flow, understøttet af god metakommunikation?

- Bliver problemformuleringen besvaret igennem rapporten og tages den op i konklusionen?

- Er terminologien konsekvent?

Hvad angår del-helhed perspektivet er det forst her, at de fleste studerende får et godt overblik over projektet og begriber det som en helhed. Det kan for eksempel udmønte sig i en skarpere titel, et mere præcist formuleret abstract, en mere dækkende indledning, udeladelse eller tilføjelse af tekstdele, et mere jævnt flow eller en skarpere konklusion.

I denne fase har de studerende en unik mulighed for at lære om laser-forfatter-perspektivet: hvordan opfatter en læser deres rapport? Booth, Colomb og Willams betoner i bogen The Craft of Research $(2003,222)$ læeserens forventninger som styrepind for læsningen og dermed læserens opfattelse af teksten. Denne forventning skabes primært $\mathrm{i}$ indledningen og tjener til, at læseren kan læse den hurtigt og forstå den bedre - fordi de ved, hvad de kan forvente, og hvorfor de skal interessere sig for den. Først med et næsten færdigt rapportudkast kan man for alvor tage fat $\mathrm{i}$ det vigtige spørgsmål: Hvilke forventninger skabes hos læseren i indledningen? Og det endnu vigtigere spørgsmål: Indfrier rapporten disse forventninger?

I slutningen af denne fase åbnes et stort potentiale men også en betydelig fare. Potentialet består i, at de studerendes og vejleders opfattelse af niveauet kan afstemmes mere præcist på grund af konvergensen mod det endelige produkt, mens faren består i »blåstemplingfælden« eller "godkendelsesfælden« hvor »Vejleder presses til at formulere eller indikere noget, der minder om godkendelse, uden at præcist - fagligt såvel som formelt - kunne argumentere for denne godkendelse« (Rienecker, Harboe og Jørgensen 2005, 291).

Hvilken feedback skal man som vejleder give tæt på aflevering og på hvilket grundlag? Jeg giver en generel karakteriserende og vurderende melding, ledsaget af detaljeret skriftlig og mundtlig feedback - både positiv og negativ. Men naturligvis centreret om hvad de studerende med rimelighed kan nå at forbedre $i$ fremstillingen. Graden af »blåstempling« i min feedback afhænger af situationen. Jeg vil altid sige »Jeg vil til enhver tid argumentere overfor censor for, at dette projekt skal bestå - baseret på følgende argumenter: ... og bemærk i øvrigt at censor kan have en anden opfattelse!« (Bemærk at jeg forudsætter, at projekter på vej mod ikke-bestået rettes op i god tid inden afleveringen nærmer sig.) De studerende bliver i øvrigt voldsomt forfærdede over denne melding, idet de tror at det tegner til 6! Det kræver en hel del uddybende forklaringer om det principielle $i$ situationen, og alene af denne grund kræver sådanne udtalelser en betydelig omtanke. Det længste jeg vil gå med hensyn til specifikt niveau er at nævne karaktergruppen: „Jeg vil argumentere overfor censor at rapporten ligger i midtergruppen, baseret på følgende argumenter: .... og bemærk iøvrigt at censor kan have en anden opfattelse! «

Efter denne redegørelse for vejledningen gennem de tre faser i projektet vil jeg diskutere problemstillingen og fokusere specielt på den tredje fase og overgangen til den fjerde fase: bedømmelsen.

\section{Absolut/relativ feedback og formativ/summativ evaluering}

Kernen i problemstillingen er forskelle og variation i forventninger hen over projektforløbet og deres grundlag. Dette kan anskues ud fra begreberne absolut og relativt. I startfasen er spændvidden i forventningerne og ambitionerne absolutte, dvs. niveauet strækker sig over hele skalaen fra halvskidt, kedeligt og redegørende til nyskabende, dristigt og originalt - alt er muligt, alle skal have mulighed for at lave et godt palads. I produktionsfasen tager bygningen form, og her opfatter jeg vejledningen som relativ, dvs. i forhold til den planlagte bygning. Skulle jeg som vejleder vurdere de studerendes arbejde absolut i produktionsfasen, dvs. i forhold til det rigtig gode, ville det i den yderste konsekvens betyde, at alle halvfærdige garager, halvfærdige huse og halvfærdige, dårlige paladser skulle kasseres, og der skulle startes forfra med at planlægge et godt palads. Så grundigere reorganisering af projektet er sjældent på dagsordenen - de studerende må indstille sig på at operere indenfor den planlagte ramme. Men det udelukker naturligvis ikke, at man som vejleder undervejs skal være opmærksom på de studerendes uafdækkede potentialer - for eksempel identificere og støtte »late bloomers $«$. 
Hen mod færdiggørelse træder bygningen frem, og perspektivet drejer væk fra det relative og hen imod det absolutte. Det kan derfor her være nyttigt at trække på begreberne formativ og summativ evaluering, som jeg kender fra mit forskningsområde Human-Computer Interaction. Her er evaluering af IT-produkter nødvendig, idet selv dygtige designere ikke kan gøre det rigtigt første gang. Tidligt i processen evalueres koncepter, senere prototyper, og til sidst færdige systemer. Formativ evaluering anvendes undervejs og har til formål at forbedre prototyperne og dermed produktet, mens summativ evaluering er en vurdering med henblik på at få et absolut niveau af det endelige produkt (Booth: An Introduction to Human Computer Interaction, 1989, 119).

\section{Om »blåstemplingsfælden « og ansvar}

Som nævnt tidligere læser jeg konsekvent endelige rapportudkast tæt på aflevering for at øge de studerendes læring på dette kritiske tidspunkt. Dette viser sig at være et følsomt område, ikke alene for de studerende, men også for vejlederne. Thomas Harboe præsenterer et eksempel på »blåstemplingsfælden" $(2005,38)$ : En vejleder vurderede niveauet af et specialeudkast til 9, hvorefter den studerende trygt afleverede specialet, som senere bedømtes til 7. Den studerende var dybt skuffet og følte sig vildledt: "Havde jeg vidst, at jeg ville få karakteren 7, havde jeg ALDRIG afleveret«. En konsekvens af dette er ifølge Thomas Harboe (2005, 42), at noget kan tyde på, at mange vejledere er tilbageholdende med at rose. Og det er jo meget uheldigt, eftersom vejledning $i$ høj grad består $i$ at mobilisere de studerendes ressourcer og styrke deres tro på, at de har potentiale til at levere et palads.

Forsøg på at undgå "godkendelsesfælden« ses naturligvis også, her i et udsagn fra en studerende: „Vejlederen holdt stejlt på ikke at læse mere end højst nødvendigt af specialet, inden det blev afleveret. På den måde var der ikke tale om en opgave, der i realiteten på forhånd var godkendt af vejleder." (Skriftlige opgaver og vejledning, Evalueringsinstituttet, 2000, 111). Og et udsagn fra en vejleder: „Vejledning og afsluttende bedømmelse ... må holdes adskilte. Det er en ubekvem situation for begge parter.« (ibid., 118). At der på den anden side er et klart behov fra studenternes side illustreres af Thomas Harboe og Rikke von Müllens $(2006,12)$ undersøgelse, hvor $72 \%$ af de studerende på jura og samfundsfag mener, at vejleder skal godkende færdigt speciale før aflevering.

Der er ikke overraskende betydelige forskelle i praksis. På visse fag kan den studerende kun aflevere 25 færdige specialesider til vejleder (Evalueringsinstituttet, 2000, 91), på andre fag læser vejleder højst 25\% af det endelige udkast (Rienecker m.fl. 2005, 63), mens visse vejledere afviser af læse noget senere end 14 dage før aflevering (ibid., 75). En studerende fortæller »Da jeg nærmede mig afslutningen på specialet havde vejleder læst ca. 1/3 af det skrevne." (Evalueringsinstituttet, 2000, 110).

Argumentet er, at man skifter rolle fra vejleder til bedømmer - som her illustreret af et udsagn fra en studerende "På et tidspunkt sagde vores vejleder, at han ikke ville vejlede os længere, fordi han ellers ville have problemer med at forholde sig objektivt til indholdet af sin endelige bedømmelse.Vi kunne faxe indledning og konklusion til ham ...» (Evalueringsinstituttet, 2000, 112).

Endelig har jeg også hørt argumentet om, at vejleder bliver ansvarlig for rapporten ved at læse endelige udkast. Sådan ser jeg det ikke. Vejleder har ansvar hele vejen igennem: for gennem den bedste vejledning at sikre, at de studerende lærer så meget som muligt og leverer et så godt produkt som muligt. Den studerende har ansvar for rapporten, og vejleder har ansvar for vejledningen. Hvis vejleder havde ansvar for rapporten, ville det i den yderste konsekvens betyde, at vejleder skulle skrive dele af rapporten, hvis den studerende ikke gad eller kunne!

Jeg medgiver, at der er et rolleskift i denne fase. Jeg er vejleder i projektperioden og bedommer til eksamen. I vejlederrollen tilstræber jeg at få de studerende til at gøre det så godt som muligt, mens jeg i bedømmerrollen tilstræber at give så loyal en vurdering som muligt i henhold til bekendtgørelser, studieordninger, osv. (At man så som vejleder i almindelighed gerne ser de studerende få en god karakter, som de er tilfredse med, må man som bedømmer sætte sig ud over.)

Sammenhængen mellem de to roller er, at jeg af al magt tilstræber at basere vejledning og bedømmelse på de samme ekspliciterede kriterier, så de studerende ikke føler, at der er forskellige grundlag for vejledning og bedømmelse. Det værste, der kan ske, er, at en studerende efter bedømmelsen siger »Det kunne du godt have sagt under vejledningen! « Det eneste væsentlige nye ved bedømmelsen bør komme fra censor, men som jo kan være uenig eller endda meget uenig med vejleder - og i værste fald vælte læsset.

En interessant tanke er at parallellisere til forholdet mellem censors og vejleders opfattelser ved bedømmelse - en anden side af samme sag. Jeg synes, det er slående, så små forskelle der er i bedømmelserne og argumentationen bagved. Der er sjældent mere end et trins forskel ${ }^{4}$. Jeg har kun en enkelt gang oplevet en censor, hvis bedømmelse afveg væsentligt fra min. Det er jo betryggende med så stor enighed her, men det sætter jo den til tider store forskel mellem de studerendes og vejleders opfattelse endnu mere i relief. Den er et vidnesbyrd om udviklingen af disse implicitte færdigheder, benævnt som "akademisk konsensus" af Elsa Schmidt i artiklen "Bedømmelsens kompleksitet" (Dansk Universitetspadagogisk Tidsskrift nr. 1, 2006, 8). 


\section{Konklusion}

At konkludere på erfaringer er ikke nødvendigvis relevant eller nødvendigt - men jeg prøver. Jeg synes der er erfaringsmæssigt belæg for, at de to metaforer for ambitioner at bygge en bygning og at gå på en vej er nyttige. De er enkle, de fanger hver væsentlige elementer, og de udspænder vejledningsrummet gennem deres vekselvirkning. Metaforerne er ikke emotionelt belastede, så drøftelsen af ambitionsniveau med de studerende afmystificeres, fokus trækkes væk fra snævre karakterbetragtninger. Mange af de studerende tager metaforerne til sig, enkelte tager undervejs spørgsmålet om ambitioner op, og de bruger da metaforerne.

Aflevering af rapportudkast tæet på aflevering giver mulighed for at give de studerende feedback på områder, som ellers kun vanskeligt kan dækkes: del-helhedsperspektivet og læser-forfatter-perspektivet. Dette er et følsomt område med meget varierende praksis, men mine erfaringer er gode og entydige.

Det samlende perspektiv for vejledning af universitetsprojekter er, at vurdering er et underliggende aspekt af vejledning, som gennemsyrer alle facetter og faser af vejledning. Handal og Lauvås udtrykker det således: »I det meste av den forskningsveiledningen vi driver, ligger det også et element av vurdering « $(2006,157)$. Med andre ord: jeg opfatter vejledning som grundlæggende baseret på vurdering i forhold til kriterier: formativ under vejledningsprocessen og summativ under bedømmelsen. Det afgørende er dels, at kriterierne er ens under vejledning og bedømmelse, og dels at de er ekspliciterede. Om ikke denne artikel har givet anledning til andet, så har den resulteret i notatet "Kvalitetskriterier i skriftlige universitetsopgaver" (Jørgensen, 2006), som jeg i årevis har tænkt på at skrive.

\section{Tak til kolleger}

Jeg er taknemmelig for værdifuld feedback undervejs fra Jan Clausen, Peter Carstensen, Søren Lauesen, Rolf Molich og to anonyme reviewere. Tak til Lotte Rienecker for henvisningen til Gunnar Handal og Per Lauvås' bog. Og tak til de mange studerende, der gennem årene har lyttet til mine mere eller mindre nyttige metaforer og refleksioner om vejledning.

\section{Litteratur}

Bloom, B., Englehart, M. Furst, E., Hill, W. og Krathwohl, D. (1956). Taxonomy of educational objectives: The classification of educational goals. Handbook I: Cognitive domain. New York, Toronto: Longmans, Green.

Booth, Paul (1989): An Introduction to Human-Computer Interaction. Lawrence Erlbaum.
Booth, Wayne, Colomb, Gregory G. og Williams, Joseph M. (2003): The Craft of Research. University of Chicago Press, 2. udgave.

Handal, Gunnar og Lauvås, Per (2006): Forskningsveilederen. Oslo: Cappelen Akademisk Forlag.

Harboe, Thomas (2000): De studerendes forventninger til specialevejledning - en spørgeskemaundersøgelse. Københavns Universitet, Det Samfundsvidenskabelige Fakultet.

Harboe, Thomas (2005): Akademisk opgavevejledning - en handlingsorienteret analyse af 51 udvalgte klagesager. Masterafhandling, Danmarks Pædagogiske Universitet.

Harboe, Thomas og Müllen, Rikke von (2006): De studerendes forventninger til specialevejledningen - en sporgeskemaundersegelse på Samfundsvidenskab og Jura. Københavns Universitet, Det Samfundsvidenskabelige Fakultet.

Jørgensen, Anker Helms (2005): Forventningsafstemning i vejledning. Vejlederbrev, IT-Universitetet i København. Fås fra forfatteren.

Jørgensen, Anker Helms (2006): Kvalitetskriterier i skriftlige universitetsopgaver. Notat, IT-Universitetet i København. Fås fra forfatteren.

Rienecker, Lotte, Thomas Harboe og Jørgensen, Peter Stray (2005): Vejledning - en brugsbog for opgave- og specialevejledere på videregående uddannelser. Samfundslitteratur.

Schmidt, Elsa (2006) Bedømmelsens kompleksitet. Dansk Universitetspadagogisk Tidsskrift, nr. 1, 6-12.

Skriftlige opgaver og vejledning. Danmarks Evalueringsinstitut, København. (2000). http://www.eva.dk/Udgivelser/Rapporter_ og_notater.aspx? $\mathrm{M}=\mathrm{Shop} \& \mathrm{PID}=351 \&$ ProductID $=67$

\section{Digitale kilder}

http://dictionary.reference.com/search?q=ambition http://www.reference.com/browse/wiki/Expectation

\section{Tre udvalgte publikationer}

Udsen, Lars Erik og Jørgensen, Anker Helms (2005): The aesthetic turn: unraveling recent aesthetic approaches to human-computer interaction. Digital Creativity, vol 16, no. 4, 218-228.

Jørgensen, Anker Helms, Garde, Anne Helene, Laursen, Bjarne og Jensen, Bente Rona (2002): Using Mouse and Keyboard under Time Pressure: Preference, Strategies and Learning. Behaviour \& Information Technology, vol. 21, no. 5, 317-319.

Jørgensen, Anker Helms (2006): Exploring the History of User Interfaces: The Myth of Xerox Parc and Other Oddities. Proc. 6th Danish HCI Research Symposium, Aarhus, Nov. 15, 2006, 29-30.

\section{Noter}

1 Disse er beskrevet i vejlederbrevet "Forventningsafstemning i vejledning" (Jørgensen, 2005).

2 Egentlig er metaforen misvisende - den burde hedde gå $i$ et landskab eftersom det at gå ud i vildnisset jo netop ikke er at gå på vejen. Men jeg har valgt at beholde den mere mundrette og forståelige vej-metafor.

3 Her må jeg tilstå, at mine egne ambitioner på Lasses vegne spillede ind.

4 Det er ikke fordi jeg har en stab af »vennecensorer«: Siden 1999 har jeg benyttet flere end 12 censorer på ITU. 